\title{
THE CORONA - AN OPPORTUNITY TO REPLACE MILITARIST SECURITY WITH COMMON AND HUMAN SECURITY11
}

\author{
Jan Oberg ${ }^{12}$, \\ Transnational Foundation for Peace and Future Research, TFF
}

\begin{abstract}
Governments have spent trillions on preparing for military threats created by their own policies. No one prioritised human and societal security. The unique over-reaction to COVID-19 should worry us much more than the virus itself. It can be seen as a panicky attempt to cover-up the failure of an outdated militarist security policy.
\end{abstract}

Keywords: Covid-19, militarism, common security, human security

\section{Introduction}

Since January 2020, about 4,9 million people have died worldwide from Covid-19 because of (or with) the Coronavirus. No other phenomenon in contemporary history has caused so many drastic decisions in democratic and authoritarian governments alike as the pandemic. Constitutions, a series of freedoms, including the freedom of movement, and much else have been suspended and new emergency laws passed fast enough to qualify for the Guinness World Records.

Let's put almost 5 million dead fellow global citizens in perspective: The Cost of War Project at Brown University puts the death toll of the US Global War on Terror (GWOT) since 2001 at an estimated 929000 people. 40000 Venezuelans have died because of the recent US sanctions on that country (Buncombe2019).About 400000 lives have been lost in the combined civil and international war of aggression since 2011 in the sovereign state and UN member, Syria, on which suffocating sanctions have also been imposed and upheld even in these times of pandemic. The Iraq War and 13 years of sanctions cost at least about 1 million civilian lives. Other wars - Afghanistan, Pakistan - have claimed at least 875.000 lives (Davies 2018). Further, may it be pointed out that more than 20000 people worldwide die every day from hunger (The World Counts 2021)?

Clobal maldevelopment, income gaps and the plight of the hundreds of millions of 'wretched of the Earth> (Fanon 1963) never caused any government, let alone all governments, to introduce any particular measures and certainly nothing as drastic as those we're now all forced to live with. Before the Coronavirus, the world issue most talked about was climate change. Our global house was in fire, to allude to Greta Thunberg's famous statement. Naomi Klein advocated a planetary state of emergency.

11 The main points of this article has been summarized in the following video made by the author: https://vimeo.com/496060959.

12 Contact address: tff@transnational.org. 
There are more reliable facts available about the many environment-related problems and their human and other costs, now and in the future, than most people can ever digest (The World Counts. Planet Earth 2021). In spite of the knowledge produced during the last 60-70 years about this global problem, few governments, if any, can be said to have done anything effective to live sustainably. Huge international conferences aimed to move towards solutions have been utter failures. But in a week or two, that issue disappeared completely. The Coronavirus won the political and the media attention.

And, not to forget, before the Coronavirus, there was increasing tension between NATO and Russia with signs of new Cold War in Europe, and there was - and is - a destructive China Cold War Agenda being acted out by the US/NATO on China. And... well, the attention winner called Corona took it all.

\section{Why this drama surrounding the Corona?}

How is it possible that much more urgent issues which cause so much more suffering and so many more deaths - and which existed for decades - have led to no drastic measures, halted governments, created a turning point - or caused us all to stand with each other and with humanity? It's quite possible that we have no real answers yet to questions such as: How did that happen so quickly? What political psychology made it possible? What makes the Coronavirus so special? But a globally-oriented sociological imagination - to use the classical eminent scholar C. Wright Mill's term (1959) - may point to some possible explanatory factors. For instance (numbers not indicative of importance):

1) Could it be that the Coronavirus has hit the richer part of the world first - China, Europe and the United States? Had 5 million people died from some disease in Africa or South America, it's quite likely that the wealthy of the Earth might not even have heard about it. The largest number of deaths from war amidst maldevelopment since the Second World War is found in the Democratic Republic of Congo (DRC). It claimed 5.4 million lives between 1998 and 2008 (Moszynski 2008). It's virtually unknown to people outside Africa.

2) Another reason could, of course, be that everything having to do with health means a lot to each of us; it's something we can all empathise with: Could it hit me and my loved ones one day? In contrast, when wars rage far away from Europe and the US, people usually do not feel threatened by them and neither do they empathise with the victims in the same manner as we have seen during these Corona times. Although at least some wars could escalate and spread and conventional wars could transform into nuclear exchanges - as official doctrines make likely and everything is planned for it - this does not seem to catch the imagination of more than a tiny minority of outcasts - peace workers. Of course, wars are sold by governments, alliances and the mainstream media as something serving a noble purpose - saving us from terrorism, spreading democracy, liberating women or making people understand human rights. While that has turned out to be consistently untrue and accompanied by demonization and lies about "the enemy", nothing noble can be found in an invisible deadly virus. In parenthesis, it is interesting to observe how the COVID-19 is talked about as a mortal danger and an invisible enemy against which we have to fight a costly war - standing patriotically together.

3) A third reason could be the dynamics of the phenomenon. It starts with a limited number of infected people and deaths at some locality (epidemic) but then spreads across 
continents and becomes a pandemic. Undoubtedly, this dynamic causes a real and legitimate sense of fear that the world shall experience an exponential growth which at some point becomes uncontrollable and threatens to cause fatalities in the millions.

4) One could also entertain a more cynical hypothesis: Like when a terror event happens, the Coronavirus pandemic provides a unique opportunity for governments and state authorities - the "Leviathan" - to both tighten the controls over their subjects or citizens and, perhaps more benevolently, to show that they also care so much for them. Fear does create a heightened willingness to abandon one's rights and can be (mis)used politically ("fearology") to suspend democracy and freedom for as long as it is deemed necessary by those very authorities who have cancelled the democratic procedures in the name of managing the threat more efficiently on behalf of the people, i.e. for the common good.

As they say, the road to Hell has often been paved with good intentions - or at least sold to the public as motivated by them. How often have we not heard, these last few weeks, presidents, prime ministers and other ministers as well as, say, police and defence authorities solemnly declare just how much they care about us citizens and how strongly they want to protect us from the danger?

One dimension of this - cynical, nasty and realistic, as you prefer - is that by locking down, demanding self-isolation and closing shops and restaurants and thereby emptying the streets, all public protests against the (mis)handling of the corona situation as well as against the lockdown of democracy and freedoms can conveniently be prevented. At least, that is, until people decide to reclaim the public spaces in the thousands and protest, violently or non-violently. No people will accept for any longer period of time to be de facto imprisoned in their homes just to avoid a virus that predominantly hits older people. And, you may add, particularly not if the governments cannot provide the basics during such a period and prove that they are in control of the calamity. The situation is potentially explosive and the more so as time goes by.

"Countries that can send precision-guided missiles and even nuclear weapons around the world, fight wars for decades and have troops stationed in faraway lands - and have stored everything needed for that - have now shown us that they are not able to, or rather never cared to, provide their own society and citizens with simple protective measures such as face masks, gloves, hand disinfection, protective clothing, thermometers, testing equipment or sufficient basic health care systems and capacities, nor to protect their own health workers."

5) Finally, there is the groupthink cover-up hypothesis. It can be expressed this way:

Covernments have spent trillions on a security paradigm that always had only one answer to every challenge no matter its character: Larger budgets, more weapons, looking strong - having the biggest. The only thing no government ever took seriously was the ideas of common human, local-to-global security and devising policies that enabled them to meet civilian threats - such as a pandemic - adequately. As a result, countries that can send precision-guided missiles and even nuclear weapons around the world, fight wars and have troops stationed in faraway lands - and have stored everything needed for that sort of policy - have not been able to, or rather cared to, provide their own society and citizens with simple protective measures such as face masks, gloves, hand disinfection, protective 
clothing, thermometers, testing equipment or sufficient basic health care systems and capacities, nor to protect their own health workers.

The official threat analyses were not aimed at telling us what in reality threatened our countries or the world. They were produced to fit the needs of the larger military system - what for years I have called the MIMAC, the Military-Industrial-Media-Academic Complex. It basically implied that you talk only about foreign enemies and their weapons (never about your own activities), and then citizens would feel threatened - and therefore convinced as taxpayers - that "we" need more weapons to feel secure against "them". Whether we are threatened by "the other" in reality and according to some decent objective criteria or not is totally unimportant. Whether this way of thinking - or the lack of it - would ever bring about a more peaceful world - who cared as long as it served the greed of the MIMAC elites? Find a policy more in need of cover-up in these corona times when it has now been revealed to the world that we indeed have no common human security. The government cover-up is simple: Oh, but we care so much for our citizens (at least since we found out that the Coronavirus was a serious thing).

It is a bit late. These policies must change. There can be no military 'business as usual' after the Coronavirus. This conflict between citizens' human security and right to peace and governments' national(istic) military security and the grotesquely huge sums spent on the latter to the detriment of the former is fundamental to the entire global system. We find it in the East and West, the South and the North, although not to the same degree everywhere.

The main military destroyers, of course, have a larger problem to face now than those who are less addicted to military power. And this civilisational problem pertains to both democracies and more authoritarian political systems - with the exception of the few countries that have decided to have no military such as Iceland and Costa Rica.

\section{How threat analyses are constructed to assist elites rather than provide security}

"There is nothing so practical as a good theory," said the father of social psychology, Kurt Lewin, as far back as in 1943. It's still true. One reason so many countries are hit now by the Coronavirus is that their governments have based their policies on a theory that is outdated, proven counterproductive and insecurity-creating and, in spite of the obvious, have wasted every opportunity to replace it with one that would both fit moral and intellectual thinking about security, defence and peace as well as humanity's future.

In the following part of the article we will seeks to explain why this is so. It is based on the author's thinking and writing about security intellectual matters since the mid-1970s. In yet another part, the idea is to illustrate how to think true security and peace in stark contrast to the contemporary militarism that can neither create stability and security in the larger world not provide protection for its own citizens. In contrast, it is brilliant in operating as a perpetuum mobile that wastes horrendous sums and destroys both economies, countries, cultures and, worst of all:

a) Has killed millions of people since 1945 and has

b) Never brought the world the defence, stability, security and peace it constantly promises if just given enough funds. 
One problem is that the last few decades have seen an almost complete de-coupling of theory from political discussions and decision-making. The defence and security discourse is devoid of creative thinking, new concepts and is simply - well, enormously boring. Making assertions with no evidence, repeating mantras - like NATO's \#stability, security and peace" no matter what it does - and stating positions has become more important than knowing what, how and why. The powers that be define what shall and what shall not be considered relevant in the discussion of a problem or policy. Of course, such a de-intellectualization can be seen in other fields of society too and in other discourses but its influence in the field of defence and security politics has now been tragically revealed by the total lack of government preparations for a world epidemic and by the panick-like reactions when it comes to human security and the closing down not only of societies but also of democracy and freedoms.

Over the years, the intellectual decay in this field is quite easy to see in just two circumstances: a) Somebody powerful, for instance, a government - backed by the military, academics in a government-funded research institution together with some leading media - points out that this or that country is a threat to "us"; and b) therefore, "we" need this or that new weapons system and a future budget which is higher than the present. What they happen to have in common is an interest in more, not less, military. It will increase their job security as well as their income - which disarmament would not. Invariably this reductionist reasoning is based on elite interests and not on genuine, diverse research approaches to what, in reality, threatens societies and human beings - militarily and in civilian terms, nationally and globally.

\section{Why are threat analyses just made to make us fear - and pay?}

First of all, threats and/enemies are selected according to what the security system has already been built and geared to handle. Since that system is dominated by the military - meaning both a tool (with weapons and the infrastructures needed to use them) and an institutional interest, what citizens are told is that there is someone that threatens their society militarily.

In this respect, let's not forget that social interests tend to settle for a worldview that maximises the utility of their own profession. To put it crudely, the priest is likely to look at many things as sinful, the peace researcher tends to point out that there are alternatives to war, such as peaceful, nonviolent conflict-resolution; and the doctor will argue that this or that is a health risk. They all - knowingly or not, intentionally or not - see what happens as something that must be met with the professional expertise they have.

Likewise, the military will argue that there are enemies out there that we have to defend against - and that the main tool to use against this enemy is more weapons which, incidentally, the military is the only appropriate institution (interest) to handle provided, that is, that it gets a larger budget. So, whereas most citizens, the mainstream media and political decision-makers still believe that, first, somebody develops an objective, comprehensive and adequate threat analysis and then the appropriate means are chosen to meet it, the reality is rather much the opposite: The threat analysis is constructed ex-post to fit the interests of the elites who are to benefit from an already ongoing policy - and would lose if it changed radically. 
Already in the 1970-80s, we used to state that: If the Soviet Union falls into the bottom of the ocean tomorrow, the US/NATO will not disarm. Rather, they will, as soon as they can, find a new "enemy" with which to legitimize their ongoing armament dynamics. To make citizens pay to satisfy these elite interests, governments have to paint a world view that is perceived as threatening - if overdone it is called fearology. And since it is usually overdone, everybody are more or less victims of fearology - of being intimidated or blackmailed to pay: We your government will take care of your safety but you will have to accept a higher price. The idea is simple and goes like this: Today we may be rather secure vis-a-vis the enemy but the enemy is rapidly developing his potential - more weapons and better weapons and better-trained and disciplined personnel - so in the near future, we shall fall behind if we don't do something- and do it now. Thus, the only realistic remedy is this: We must increase our military strength as soon as we can to bring about a 'balance' with the enemy and thereby deter him from attacking us. An added standard ingredient is: We, on our side, have only defensive intentions but we are anything but sure that the same can be said about the enemy with his behaviour, ideology, history or type of government.

It doesn't take an Einstein to see the obvious: When the appointed enemy thinks exactly the same way about us, there is a perfect armament dynamics in place, always upward - no matter what the real world looks like. And it will continue undisturbed by reality until some people begin to - think. Think of what is actually going on - and how they are fooled - and begin to think that perhaps there could be other ways of creating security and peace than this.

\section{The theory of the calibrated threat}

Here appears a sub-theory about all this: The theory of the calibrated threat. What does that mean? It means that the enemy/threat has to look big and serious enough to legitimize our armament and the allocation of tax-payers money to it. If the threat is presented as too small or having too little probability, it may dawn upon the citizens that they could just as well do without a military and spend the money on something more fun and rewarding such as schools or culture.

That would be terrible for the military and the government whose policies rest exclusively on it. On the famous other hand, the threat/enemy must not be painted as huge, overwhelming and too likely - such as an impending nuclear attack. Why not? Because, if the enemy and the threat is much much larger than we on our side can realistically meet with our means, there would be a strong argument for closing down our defence establishment: If that threat happens, there is anyhow nothing we can meaningfully do to guard against it or fight it if it happens - so that would be a waste of funds.

In consequence, we always learn about threats that are big enough to be meaningful for our defence to meet (with more money) - but never the type that is too small to need any action and also never so devastating, probable and so much beyond our capacity that we could just as well do nothing and spend society's funds on something better and hope for the best.

In a brilliantly creative book from 1973, "Tools for Conviviality," Ivan Illich (2001, p. 58) defines 'radical monopoly' in this manner: 
"The establishment of radical monopoly happens people give up their native ability to do what they can do for themselves and for each other, in exchange for something "better" that can be done for them by a major tool. Radical monopoly reflects the industrial institutionalization of values. It substitutes the standard package for the personal response...Against this radical monopoly, people need protection ... The costs of radical monopoly is already borne by the public and will be broken only if the public realizes that it would be better off paying the costs of ending the monopoly than by continuing to pay for its maintenance."

Many years later - today - this radical monopoly has also developed into a military monopolization. Over time, the military as an institution has become all-powerful. It professes to be able to do all kinds of things: Yes, it can defend our country against external enemies if attacked but it can also fight the enemy far away - think for instance of the US's $600+$ military bases and tens of thousands of troops, technicians and secret operatives in virtually every country around the world. And not only that.

The military supports re-building of destroyed societies and nation-building, protects and develop democracy and human rights. It can be used as law-and-order domestically, it's involved in cyber defence, the Global War on Terror (a war that has only created more terrorism and hatred worldwide and also, here and there like in Syria, supported terrorism as part of a regime-change policy. Lately, the military has also presented itself as the great defender of the environment, ready to assist in environmental protection, stop asylum seekers at the border (walls), move refugees around etc - and itself become a 'green' military and reduce its carbon footprint, etc.

We are in a situation where democracies have become manifestly militaristic which has little to do with the traditional indicators of militarism such as military parades, uniform, discipline, music and the flag but has everything to do with the military institutions taking over civilian functions of our society. The overarching term for this is isomorphism: The military sector becomes more and more civilian too and society becomes militarised. With that follows that the civil society becomes more and more like the military - increasingly vertical, non-democratic and ready for the strong leadership on top - not unlike an army.

Militarism spells the end of democracy and of the vision of the good society at peace with itself and others. A militarist society is one in which the military takes over more and more of the purely civilian functions while, simultaneously, maintaining and expanding its traditional military roles. To such an extent that there is no civilian, human security policies left. That is where the far majority of the world's countries are today - the larger military spenders, in particular. Addicted as they are to militarism, no matter the problem they face.

Indeed, vis-a-vis the over-armament, wars and depletion of resources much needed for the development/justice issue, climate change and other global issues and reforms, the people need protection against this monopoly, as it increases the insecurity for all, perhaps with the exception of the elites whose interests it serves. This 'radical' monopoly can also be interpreted to mean that the military - among many other institutions - have gained top priority. 
Try to ask anybody around the world with what she or he associates the word "defence" or the word "security"? The first associative word $99 \%$ of them will come up with is "the military" or "defence." Few - very few - would answer something like - oh, then I think first and foremost of me and my family having a good protection in terms or health, safety in the streets, a high degree of self-reliance so that we shall not be in need of any basic things if there is an economic crisis - or something similar.

Humanity has been programmed to believe that defence and security is, first and foremost, a matter of having a strong military. That sort of security is national, governmental, about $97 \%$ military and $3 \%$ civil and elitist/professional. We call this concept "national security" or "defence" policy" in daily conversation, debates - and in the state budgets. Potentially, it is the most fatal myth humanity has been fed with. Its end station is called nuclear annihilation - omnicide.

\section{The most important lesson to learn}

Let's conclude that the Corona is much more than a health issue: It's a security political problem - a disaster. It proves with abundant clarity that the military-dominated security paradigm and politics pursued by virtually all governments have been wrong in theory and practice all the time. It shows how counterproductive and irresponsible it is particularly in what we used to call democracies. That outdated policy has been oriented towards the wrong "enemy" and done unspeakable harm to humanity and to Nature (see examples above).

It must go. A new way of thinking must now emerge, demanded by the people whose security has been so arrogantly ignored. The Corona pandemic is our best-ever wake-up call. The Coronavirus shows, more than anything, that that thinking and those policies can be compared with a virus, the Militarismvirus. There can be no "business as usual" after this pandemic. It must force through a huge conversion from a predominantly military to a predominantly civilian security thinking, doctrine, threat analyses and general policy. It must imply a huge transfer of resources from the world's military and war budgets to civil human and global security. The world's military budgets are the only reservoirs from which funds can be taken to finance the solutions to the other mentioned global problems.

\section{References}

Buncombe Andrew (2019), "US sanctions on Venezuela responsible for 'tens of thousands' of deaths, claims new report", Independent, 26 April, online https://www.independent. co.uk/news/world/americas/venezuela-sanctions-us-excess-death-toll-economy-oil-trumpmaduro-juan-guaido-jeffrey-sachs-a8888516.html.

Davies Nicolas J.S. (2018), "How many people has the U.S. killed in its post-9/11 wars? Part 2: Afghanistan and Pakistan", Consortium News, 3 April, online https:// consortiumnews.com/2018/04/03/how-many-people-has-the-u-s-killed-in-itspost-9-11-wars-part-2-afghanistan-and-pakistan/?fbclid=IwAROLNx1F5jnnFHsi9zqrt57jN5eSTUWzhcW7FAG3B43aUz2ABJPeTb06DY. 
Fanon Frantz (1963), Wretched of the Earth, NY: Grove Press, online: https://vt.instructure. com/courses/23718/files/886914.

Illich Ivan (2001), Tools for Conviviality, Marion Boyars Publishers.

Mills C. Wright (1959), The Sociological Imagination, NY: Oxford University Press, online: https://www.imprs-demogr.mpg.de/courses/01ws/TSI.pdf.

Moszynski Peter (2008), "5.4 million people have died in Democratic Republic of Congo since 1998 because of conflict, report says", BMJ, 2 February 2, 336(7638): 235, D0I: 10.1136/ bmj.39475.524282.DB.

The World Counts (2021), online: https://www.theworldcounts.com/challenges/people-andpoverty/hunger-and-obesity/how-many-people-die-from-hunger-each-year/story.

The World Counts. Planet Earth (2021), online: https://www.theworldcounts.com/challenges/ planet-earth. 